\title{
PENGARUH JUMLAH UANG BEREDAR,TINGKAT SUKU BUNGA DAN INFLASI TERHADAP PERTUMBUHAN EKONOMI DI INDONESIA
}

\author{
Asnawi ${ }^{1}$, Hafizatul Fitria ${ }^{\text {a2 }}$ \\ ${ }^{a}$ Fakultas Ekonomi dan Bisnis Universitas Malikussaleh \\ 1Corresponding author: asnawi@unimal.ac.id \\ 2 hafizatulfitria56@gmail.com
}

ARTICLE INFORMATION

Keywords: Money Supply Amount, Interest Rate, Inflation, Economic Growth..

\section{A B S T R A C T}

The purpose of this study is to determine the effect of the money supply, interest rates, and inflation on economic growth in Indonesia. The data analysis method used is Multiple Linear Regression. The data used are time series data from 1999-2017 which were interpolated. The results partially show that the money supply and inflation have a positive and significant influence on economic growth in Indonesia, while interest rates do not affect economic growth in Indonesia. Simultaneously the money supply, interest rates and inflation have a significant influence on economic growth in Indonesia

\section{PENDAHULUAN}

Pembangunan ekonomi pada hakikatnya merupakan serangkaian usaha kebijaksanaan pemerintah dalam mencapai suatu hasil yang positif yang berdampak kepada kesejahteraan masyarakat. Pembangunan ekonomi bertujuan meningkatkan taraf hidup manusia, meningkatkan kesempatan kerja dengan diimbangi perluasan jumlah lapangan pekerjaan dan mengatur penggolongan pendapatan secara merata di setiap wilayah (Siburian \& Dkk, 2013).

\section{Menurut Djojohadikusumo}

pertumbuhan ekonomi merupakan kegiatan produksi yang melibatkan barang dan jasa dengan menggunakan prasarana dan sarana produksi. Menurut Schumpeter dalam Boediono (1992) pertumbuhan ekonomi adalah meningkatnya penggunaan factor produksi dalam proses produksi tanpa adanya perubahan cara dan teknologi yang digunakan yang mengakibatkan meningkatnya output masyarakat. Persamaan pertumbuhan ekonomi bukan sekedar menghitung tingkat perkembangan pengeluaran suatu perekonomian, akan tetapi juga memberikan tanda tentang aktivitas perekonomian yang terjadi pada periode tertentu menghasilkan pemasukan bagi masyarakat (Komariyah \& Dkk, 2016). Kesetabilan perekonomian suatu negara menjadi tolak ukur bagi perkembangannya perekonomian secara berkelanjutan.

Permasalahan ekonomi yang menjadi perhatian para ekonom adalah inflasi. Menurut Sudarso (1991), inflasi merupakan indeks ekonomi makro, digunakan untuk mengukur kestabilan ekonomi suatu negara. Perubahan indeks ekonomi makro ini berakibat pada pertumbuhan ekonomi. Suku bunga Bank Indonesia menjadi indikasi bagi perbankan untuk menentukan tingkat suku bunganya, seperti tabungan, deposito dan kredit, hal ini merupakan satu dari beberapa faktor yang mempengaruhi inflasi.

Menurut Yodiatmaja (2012) perkembangan BI rate dapat memengaruhi beberapa variabel makro ekonomi kemudian dilanjutkan ke inflasi. Naiknya level BI rate yaitu untuk mengurangi kecepatan aktifitas ekonomi yang bisa memicu inflasi. Ketika suku bunga kredit serta desposito naik, ini dikarenakan peningkatan level BI rate dan selanjutnya hal ini menyebabkan masyarakat lebih condong menyimpan uang di bank mengakibatkan jumlah uang beredar berkurang. Meningkatnya suku bunga akan menjadikan para pelaku usaha menurunkan investasi dikarenakan biaya modal semakin tinggi. Hal tersebut meredam kegiatan 
ekonomi sehingga dapat mengurangi tekanan inflasi.

Berdasarkan data BPS, inflasi indonesia tahun 2011 sebesar 3,79\%. Terjadinya inflansi di Indonesia karena tingginya permintaan agregat, sedangkan permintaan sebuah produk tidak sesuai dengan kemampuan produksi serta kenaikan anggaran produksi. Inflasi di tandai dengan meningkatnya harga barang serta jasa dengan merata. Hal tersebut dapat menyebabkan turunnya daya beli masyarakat terhadap barang dan jasa, kemudian berakibat pada lemahnya aktivitas perekonomian, melemahnya nilai rupiah serta ketidakstabilan perekonomian negara.

Berdasarkan sumber inflasi dapat digolongkan menjadi dua,yaitu inflasi tarikan permintaan dan dorongan biaya. Kestabilan inflasi merupakan hal terpenting bagi bank indonesia. Apabila inflasi tidak dalam basis yang ditentukan maka Bank Indonesia mengitervensi melalui suku bunga kebijakan. Suku bunga nominal dinaikan pada saat inflasi meningkat yang akan mendorong masyarakat untuk melakukan investasi ke sektor produktif agar dapat memenuhi permintaan yang terjadi dipasar (Boediono, 1998).

\section{Tabel 1}

Jumlah Uang Beredar, Suku Bunga, Inflasi Dan Pertumbuhan Ekonomi Indonesia 2012-2017

\begin{tabular}{|c|c|c|c|c|}
\hline Tahun & $\begin{array}{c}\text { Jumlah Uang } \\
\text { Beredar } \\
\text { (milyar) }\end{array}$ & $\begin{array}{c}\text { Suku } \\
\text { Bung } \\
\mathrm{a} \\
(\%)\end{array}$ & $\begin{array}{c}\text { Inflasi } \\
(\%)\end{array}$ & $\begin{array}{c}\text { Pertum } \\
\text { buhan } \\
\text { Ekono } \\
\mathrm{mi} \\
(\%)\end{array}$ \\
\hline 2015 & $1.055 .439,82$ & 7,50 & 3,35 & 4,79 \\
\hline 2016 & $1.237 .642,57$ & 6,50 & 3,02 & 5,0 \\
\hline 2017 & $1.341 .886,98$ & 4,25 & 3,61 & 5,2 \\
\hline
\end{tabular}

Sumber data: Bank Indonesia, 2017

Dari data tabel 1 diketahui bahwa jumlah uang beredar di indonesia meningkat dengan pesat setiap tahunnya, dimana tahun 2015 jumlah uang beredar sebesar 1.055.439,82 milyar, tingkat suku bunga sebesar 7,50, inflasi sebesar 3,35\% dengan pertumbuhan ekonomi sebesar 4,75. Dan pada tahun 2017 jumlah uang beredar naik sebesar 1.341.886,98 milyar, suku bunga menjadi 4,25\%, laju inflasi $3,61 \%$ dengan pertumbuhan ekonomi meningkat sebesar 5,2\%. Hal ini tidak sesuai dengan teori dimana jumlah uang beredar berpengaruh positif terhadap pertumbuhan ekonomi, inflasi berpengaruh negatif terhadap pertumbuhan ekonomi dan suku bunga berpengaruh positif terhadap pertumbuhan ekonomi. dimana suku bunga mempengaruhi jumlah uang sekaligus mempengaruhi inflasi yang selanjutnya juga akan berakibat terhadap pertumbuhan ekonomi.

Untuk mencapai serta menjaga tingkat inflasi yang rendah dan stabil dibutuhkan kerja sama dari semua pihak bank Indonesia, pemerintah maupun swasta. Inflasi yang tinggi penting diperhatikan mengingat dampaknya terhadap perekonomian yang dapat menimbulkan ketidakstabilan pertumbuhan ekonomi yang lambat. Berdasarkan latar belakang, penulis tertarik melakukan penelitian berjudul: "Pengaruh Jumlah Uang Beredar, Tingkat Suku Bunga dan Inflasi Terhadap Pertumbuhan Ekonomi di Indonesia".

\section{TINJAUAN TEORITIS}

\subsection{Pertumbuhan Ekonomi}

Pertumbuhan ekonomi merupakan proses perkembangan hasil pengeluaran perkapita jangka panjang yang bersumber dari kapasitas yang ada dalam perekonomian tersebut, bukan bersumber dari luar yang sifatnya sementara (Boediono, 1994). Sedangkan menurut Arsyad (1997) pertumbuhan ekonomi adalah peningkatan GDP atau GNP tanpa meninjau apakah peningkatan tersebut lebih besar atau kecil dari tingkat pertumbuhan penduduk serta apakah terjadi perubahan struktur ekonomi.

\subsection{Jumlah Uang Beredar}

Hubbard \& Dkk (2005) mengatakan jumlah uang beredar ialah "the total quantity of money in the economy". Jika diartikan secara bebas,maka uang beredar adalah jumlah atau keseluruhan uang dalam perekonomian.

\subsection{Tingkat Suku Bunga}

Alokasi modal dari peusahaan dilihat dari suku bunga perusahaan dengan peluang investasi menguntungkan serta mampu membayar imbalan tinggi atas modal, sehingga akan menarik modal dari perusahaan yang tidak efisien. 


\section{$2.4 \quad$ Inflasi}

Meningkatnya harga dalam waktu lama yang terjadi pada barang serta jasa, hal ini disebut dengan inflasi. Apabila terjadi kenaikan harga satu atau dua hari terhadap suatu jenis barang hal ini tidak dapat disebut inflasi. Lawan inflasi merupakan deflasi, deflasi ialah menurunnya harga secara terus menerus.

\section{METODE PENELITIAN}

Objek yang digunakan dalam penelitian adalah Jumlah uang beredar, tingkat suku bunga, inflasi dan pertumbuhan ekonomi. Dan lokasi penelitian di Indonesia.

Data yang digunakan dalam penelitian adalah data sekunder selama periode 1999-2017 yang diperoleh dari instansi terkait yaitu BPS, BI (Bank Indonesia) dan sumber-sumber lainnya yaitu jurnal-jurnal dan hasil penelitian. Adapun data yang digunakan dalam penelitian adalah jumlah uang beredar, tingkat suku bunga, inflasi, dan pertumbuhan ekonomi.

\subsection{Definisi Operasional Variabel}

Variabel penelitian merupakan nilai dari objek atau kegiatan yang memiliki variasi tertentu yang ditetapkan oleh peneliti untuk dipelajari dan ditarik kesimpulan (Sugiyono, 2008). Definisi operasional merupakan petunjuk tentang bagaimana variabel-variabel dalam penelitian diukur.

Berdasarkan hipotesis yang telah disusun, maka penulis menggunakan variabel-variabel sebagai berikut :

1. Varibel Jumlah uang beredar merupakan uang yang ada ditangan masyarakat sebagai alat alat tukar menukar. Jumlah uang beredar terdiri dari uang kartal dan uang giral. (satuan milyaran Rp)

2. Tingkat suku bunga merupakan harga dari penggunaan uang yang di nyatakan dalam persen untuk jangka waktu tertentu. (Satuan \%)

3. Variabel Inflasi merupakan keadaan dimana tingkat harga secara umum cenderung naik. (Satuan \%)

4. Variabel pertumbuhan ekonomi merupakan perubahan kondisi perekonomian suatu negara secara kesinambungan menuju keadaan lebih baik selama periode tertentu. Ukuran yang sering digunakan dalam mengukur pertumbuhan ekonomi adalah PDB atas dasar harga konstan. (Satuan \%)

\subsection{Metode Analisis Data}

Analisis data yang digunakan dalam penelitian yaitu analisis kuantitatif. Analisis kuantitatif merupakan analisis yang menggunakan angka-angka dengan perhitungan statistik. Bila observasi atau pengukuran dapat dinyatakan dalam angka-angka maka kumpulan observasi atau pengukuran itu dinamakan data kuantitatif (Dajan, 2000). Analisis data kuantitatif dilakukan untuk mengetahui apakah variabel bebas berpengaruh terhadap variabel terikat dengan menggunakan analisis regresi linier berganda. Menurut Sugiyono (2011) rumus analisis regresi linier berganda yaitu sebagai berikut:

$$
Y=\alpha+\beta_{1} \log X_{1}+\beta_{2} X_{2}+\beta_{3} X_{3}+e
$$

Keterangan:

$\mathrm{Y}=$ Pertumbuhan Ekonomi

$\mathrm{a}=$ konstanta

$\mathrm{b}=$ Koefisien Regresi Berganda

$\mathrm{X} 1=$ Jumlah Uang Beredar

$\mathrm{X} 2$ = Tingkat suku bunga

$\mathrm{X} 3=$ Inflasi

$\mathrm{E}=$ Error Term

\section{HASIL PENELITIAN DAN PEMBAHASAN}

\subsection{Deskriptif Variabel Penelitian}

\subsubsection{Perkembangan Pertumbuhan Ekonomi di Indonesia}

Pertumbuhan Ekonomi merupakan salah satu poin penting dalam melakukan analisis pembangunan ekonomi yang terjadi pada suatu negara. Pertumbuhan ekonomi merupakan salah satu ukuran dari hasil perkembangan yang dilaksanakan, khususnya bidang ekonomi pertumbuhan tersebut merupakan gambaran tingkat perkembangan ekonomi terjadi.

\subsubsection{Perkembangan Jumlah Uang Beredar Di Indonesia}

Uang beredar adalah kewajiban sistem moneter (Bank sentral,Bank Umum,dan Bank pengkreditan Rakyat/BPR) terhadap sektor swasta Domestik (tidak termasuk pemerintah pusat dan bukan penduduk). Uang Beredar dapat disebutkan 
dalam arti sempit (M1) serta dalam arti luas (M2). M1 meliputi uang kartal serta uang giral (giro berdenominasi Rupiah), Sedangkan M2 meliputi M1, uang kuasi (mencakup tabungan, simpanan berjangka dalam rupiah dan valas, serta giro dalam (valuta asing) dan surat berharga yang dikeluarkan oleh sistem moneter yang dimiliki sektor swasta domestik dengan jangka waktu sampai satu tahun.

\subsubsection{Perkembangan Tingkat Suku Bunga di Indonesia}

Bank Indonesia mengartikan BI Rate sebagai "the policy rate reflecting the monetarybthe policy stance adopted by bank indonesia and announced the public"(www.bi.go.id). $\mathrm{Bi}$ rate berfungsi mengelola likuiditas pasar dalam mencapai target operasional dari kebijakan moneter. Tujuan Bi rate juga untuk menjaga perekonomian tetap normal dan mengontrol inflasi.

Pada saat level tingkat suku bunga meningkat maka suku bunga kredit dan deposito juga akan cenderung meningkat. Ketika suku bunga deposito meningkat maka masyarakat memilih menyimpan uang pada bank-bank dan uang beredar di masyarakat akan berkurang. Pada saat suku bunga kredit, kenaikan suku bunga akan memicu pelaku usaha untuk mengurangi investasi karenakan biaya modal yang tinggi.

\subsubsection{Perkembangan Inflasi Di Indonesi}

Inflasi adalah kenaikan harga scara terus menerus. Pada tahun 1998 saat negara kita dilanda krisis keuangan sebagai akibat dari lemahnya nilai tukar rupiah terhadap dolar amerika, sebagian besar masyarakat kita secara mendadak mengalami "pemiskinan"atas kekayaan yang mereka simpan dan miliki. Inflasi tahun 1998 itu diawali dan sudah dimulai awal tahun 90-an.saat itu ( tahun 1990 an)ekonomi negara kita sedang tumbuh dan berkembang dengan hangat-hangat nya.Ibarat gadis cantik belia,Indonesia menarik banyak mata negara dan investor dalam mengembangkan bisnis mereka,dan karena itu tentu saja mereka membutuhkan rupiah untuk memulai aktifitas bisnis merka di indonesia.

\subsection{Uji Normalitas}

Uji normalitas diperlukan untuk mengetahui distribusi data, apakah berdistribusi normal atau tidak.Pada penelitian ini uji normalitas yang dilakukan menggunakan tabel HistogramNormality

Test.

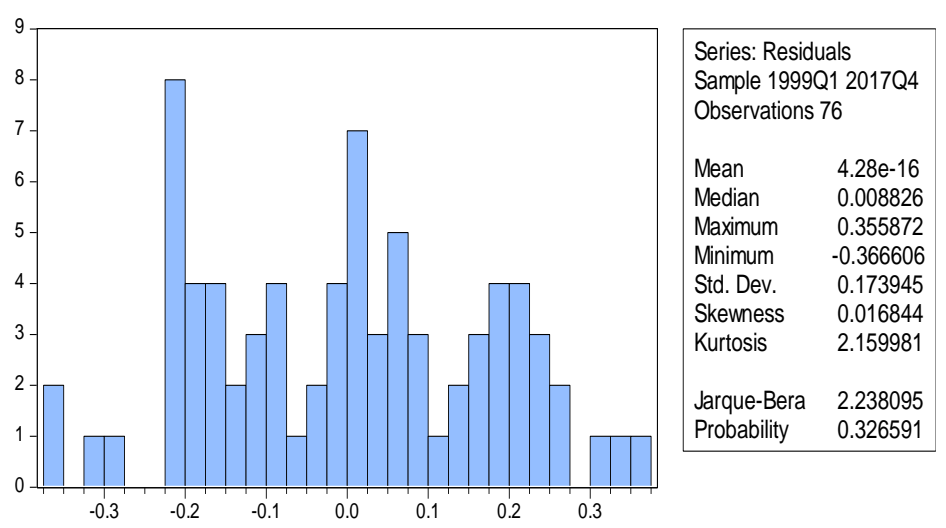

Sumber : Hasil Penelitian (Data Diolah:2018)

\section{Gambar 1}

Hasil Uji Normalitas

Untuk mengetahui normal atau tidak normalnya model regresi, variabel pengganggu yaitu dengan cara membandingkan nilai J-B hitung dengan nilai $\square^{2}$ (Chi-Square) tabel. Nilai $\square^{2}$ tabel dengan df $=$ $76-4=72$ sebesar 92,8083. Jika dibandingkan dengan nilai J-B pada gambar diatas sebesar 2,238095 maka dapat disimpulkan bahwa model regresi, variabel pengganggu atau residual berdistribusi normal karena nilai J-B $<$ nilai $\square^{2}$ tabel $(2,238095<92,8083)$.

\subsection{Uji Asumsi Klasik}

\subsubsection{Uji Multikolineritas}

Uji multikolinearitas digunakan untuk mengetahui ada tidaknya hubungan antar variabel bebas pada penelitian.

Tabel 2

Hasil Uji Multikolinieritas

\begin{tabular}{|c|c|c|c|}
\hline & JUB & SUKUBUNGA & INFLASI \\
\hline JUB & 1.000000 & -0.391475 & -0.327414 \\
\hline SUKUBUNGA & -0.391475 & 1.000000 & -0.147661 \\
\hline INFLASI & -0.327414 & -0.147661 & 1.000000 \\
\hline
\end{tabular}

Sumber : Hasil Penelitian (Data

Diolah:2018)

Hasil analisis menunjukkan bahwa koefisien korelasi antar variabel bebas $<0,8$ yang berarti bahwa tidak terdapat multikolinearitas pada masing-masing variabel bebas. 


\subsubsection{Uji Heteroskedastisitas}

Cara mendeteksi terjadi atau tidaknya heteroskedastisitas dalam model regresi adalah dengan cara menggunakan Breusch-PaganGodfrey.

\section{Tabel 3}

\section{Hasil Uji Heteroskedastisitas}

\begin{tabular}{|l|l|l|l|}
\hline Heteroskedasticity Test: Breusch-Pagan-Godfrey \\
\hline F-statistic & 1.773856 & Prob. F(3,72) & 0.1598 \\
\hline Obs*R-squared & 5.230614 & Prob. Chi- & Square(3) \\
\hline Scaled explained SS & 2.722773 & $\begin{array}{l}\text { Prob. Chi- } \\
\text { Square(3) }\end{array}$ & 0.1557 \\
\hline \multicolumn{4}{|c|}{ Sumber } \\
\hline
\end{tabular}

Diolah:2018)

Berdasarkan tabel 3 diketahui bahwa nilai p-value yang ditunjukkan dengan nilai prob. chi square (3) pada obs*R-Squared yaitu sebesar 0.1557 . Oleh karena nilai $\mathrm{p}$ value $0.1557>0,05$ maka dapat disimpulkan tidak terjadi heteroskedastisitas.

\subsubsection{Uji Autokorelasi}

Salah satu uji untuk mendeteksi autokorelasi adalah dengal uji Serial Correlation LM Test. Berikut nilai hasil olah data autokorelasi.

\section{Tabel 4}

\section{Uji Autokorelasi Metode}

Breusch-Godfrey Serial Correlation LM Test:

\begin{tabular}{lclc}
\hline \hline $\begin{array}{l}\text { F-statistic } \\
\text { Obs*R- }\end{array}$ & 156.4511 & Prob. F(2,70) & 0.0000 \\
squared & 62.10611 & Prob. Chi-Square(2) & 0.0000 \\
\hline \hline
\end{tabular}

Test Equation:

Dependent Variable: RESID

Method: Least Squares

Date: 08/28/18 Time: 08:40

Sample: 1999Q1 2017Q4

Included observations: 76

Presample missing value lagged residuals set to zero.

\begin{tabular}{crrr}
\hline \hline Variable & Coefficient & Std. Errort-Statistic & Prob. \\
\hline \hline C & 0.019616 & 0.1860520 .105433 & 0.9163 \\
& & - & \\
LOG(JUB) & -0.001580 & 0.0143530 .110081 & 0.9127 \\
SUKUBUN & & - & \\
GA & -0.000337 & 0.0187950 .017954 & 0.9857 \\
& & - & \\
INFLASI & -0.000318 & 0.0022950 .138756 & 0.8900 \\
RESID(-1) & 1.305475 & 0.10369212 .58995 & 0.0000 \\
RESID(-2) & -0.501240 & 0.104146 & - \\
\end{tabular}

4.812885

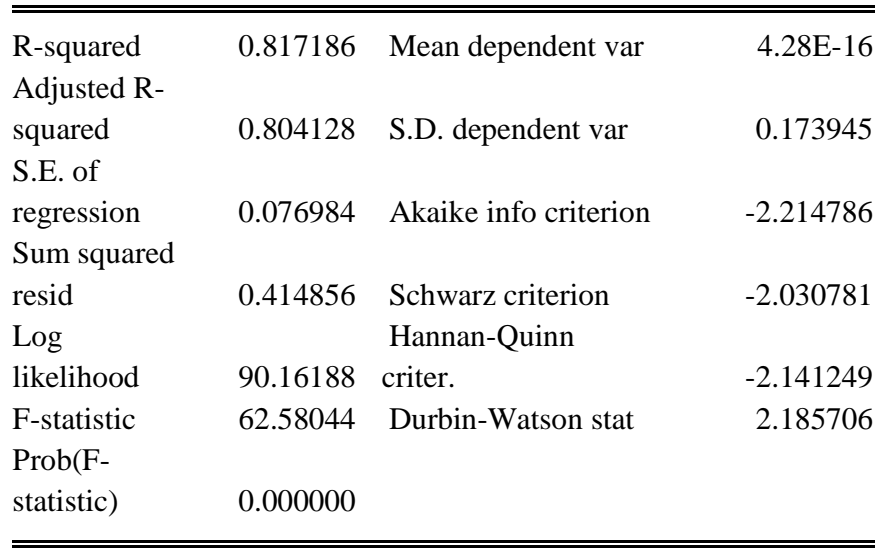

Sumber : Hasil Penelitian (Data Diolah:2018)

Berdasarkan tabel 4 diketahui nilai Durbin Watson sebesar 2,1857. Berdasarkan tabel tersebut diperoleh $\mathrm{dL}$ dan dU dengan $\mathrm{K}=4$ dan $\mathrm{n}=76$ adalah masing-masing 1.5190 dan 1.7399 maka keputusan untuk mengatakan bahwa model terbebas dari masalah autokorelasi apabila $4-\mathrm{dL}$ $>\mathrm{d}<4-\mathrm{dU}(4-1.5190>2.1857<4-1.7399$ atau $2.4810>2.1857<2.2601)$ bisa diterima. Kesimpulannya yaitu tidak terjadinya autokorelasi di dalam penelitian ini.

\subsection{Analisis Regresi Linier Berganda}

Untuk mengetahui hasil penelitian dilihat dari output regresi linier berganda menggunakan Eviews sebagai alat analisis. Berikut hasilnya pada tabel 5 :

Tabel 5

Hasil Regresi Jumlah Uang Beredar, Suku Bunga, Dan Inflasi Terhadap Pertumbuhan Ekonomi Di Indonesia

\begin{tabular}{|lrrrr|}
\hline \multicolumn{1}{|c}{ Variable } & \multicolumn{1}{c}{ Coefficient } & Std. Error & t-Statistic & Prob. \\
C & -0.173976 & 0.427513 & -0.406950 & 0.6853 \\
LOG(JUB) & 0.109971 & 0.033012 & 3.331215 & 0.0014 \\
SUKUBUNG & & & & \\
$\quad$ A & 0.149141 & 0.043132 & 3.457783 & 0.0009 \\
$\quad$ INFLASI & -0.049032 & 0.005283 & -9.280340 & 0.0000 \\
R-squared & 0.725609 & Mean dependent var & 1.254605 \\
Adjusted R- & & & \\
squared & 0.714176 & S.D. dependent var & 0.332069 \\
S.E. of & & & \\
regression & 0.177532 & Akaike info criterion & -0.568133 \\
Sum squared & & & \\
resid & 2.269273 & Schwarz criterion & -0.445463 \\
Log & & & \\
likelihood & 25.58907 & Hannan-Quinn criter. & -0.519108 \\
F-statistic & 63.46639 & Durbin-Watson stat & 0.257982 \\
Prob(F- & 0.000000 & & \\
\hline
\end{tabular}


statistic)

Sumber : Hasil Penelitian (Data

Diolah:2018)

Berdasarkan data dari Tabel 5 di atas dapat dibuat persamaan regresi linier berganda sebagai berikut:

$$
\mathrm{Y}=-0.173976+0.109971 \text { LOG }(\mathrm{JUB})+
$$

$0.149141 \mathrm{SB}-0.049032 \mathrm{INF}$

Dari persamaan model regresi diatas maka hasil penelitian dapat dinyatakan sebagai berikut:

- Konstanta $\left(\beta_{0}\right)=-0.173976$. Apabila jumlah uang beredar, suku bunga, dan inflasi tahun sebelumnya dianggap konstan (nol) maka pertumbuhan ekonomi adalah sebesar -0.173976.

- Koefisien regresi jumlah uang beredar $\left(\beta_{1}\right)$ $=0.109971$. Apabila jumlah uang beredar meningkat sebesar 1\%, maka akan meningkatkan pertumbuhan ekonomi sebesar $0.109971 \%$.

- Koefisien regresi suku bunga $\left(\beta_{2}\right)=$ 0.149141. Apabila suku bunga meningkat sebesar $1 \%$, maka akan meningkatkan pertumbuhan ekonomi sebesar 0.149141 $\%$.

- Koefisien regresi inflasi $\left(\beta_{3}\right)=-0.049032$. Apabila inflasi meningkat sebesar $1 \%$, maka akan pertumbuhan ekonomi turun sebesar $-0.049032 \%$.

\subsection{Pembuktian Hipotesis}

\subsubsection{Uji Parsial (t)}

Uji t merupakan sebuah metode pengujian untuk mengetahui sejauh mana pengaruh atau hubungan varibel secara parsial (satu-satu) yaitu antara variabel $\mathrm{X}$ terhadap variabel $\mathrm{Y}$, dimana jika penelitian dan pengolahan data dijumpai nilai $t_{\text {hitung }}>t_{\text {tabel }}$ maka hipotesis alternatif $\left(\mathrm{H}_{\mathrm{a}}\right)$ diterima dengan level of signifikansi atau $\alpha=5 \%$ sedangkan jika $t_{\text {hitung }}<\mathrm{t}_{\text {tabel }}$ maka hipotesis null $\left(\mathrm{H}_{0}\right)$ ditolak dengan level of signifikansi atau $\alpha=5 \%$. Dari hasil pengujian pada tabel 4.4 menunjukkan bahwa:

1. Jumlah uang beredar mempunyai $\mathrm{T}_{\text {hitung }}$ sebesar 3.3312, dengan nilai probabilitas statistiknya sebesar 0,0014 dan nilai $\mathrm{T}_{\text {tabel }}$ dengan $(\mathrm{df})=\mathrm{n}-\mathrm{k}(76-4=72)$ pada $\alpha=$
5\% . Dapat disimpulkan bahwa $\mathrm{T}_{\text {hitung }}$ $>\mathrm{T}_{\text {tabel, }}$ atau $\quad 3.3312>1.9934$ dengan signifkansi 5\%, maka keputusannya yaitu hipotesis $\mathrm{H}_{\mathrm{a}}$ diterima dan hipotesis $\mathrm{H}_{0}$ ditolak, yang berarti secara parsial jumlah uang beredar berpengaruh signifikan dan positif terhadap pertumbuhan ekonomi di Indonesia.

2. Suku bunga memiliki $\mathrm{T}_{\text {hitung }}$ sebesar 3.4578 dengan nilai probabilitas statistiknya sebesar 0.0009 dan nilai $\mathrm{T}_{\text {tabel }}$ dengan $(\mathrm{df})=$ n-k $(76-4=72)$ pada $\alpha=5 \%$. Dapat disimpulkan bahwa $T_{\text {hitung }}>T_{\text {tabel, }}$ atau 1,603 > 1,9934 dengan signifkansi 5\%, maka keputusannya yaitu hipotesis $\mathrm{H}_{\mathrm{a}}$ diterima dan hipotesis $\mathrm{H}_{0}$ ditolak, yang berarti secara parsial suku bunga berpengaruh signifikan dan positif terhadap pertumbuhan ekonomi di Indonesia.

3. Inflasi memiliki $\mathrm{T}_{\text {hitung }}$ sebesar -9.2803, dengan nilai probabilitas statistiknya sebesar 0,0000 dan nilai $\mathrm{T}_{\text {tabel }}$ dengan $(\mathrm{df})=$ n-k $(76-4=72)$ pada $\alpha=5 \%$. Dapat disimpulkan bahwa $\mathrm{T}_{\text {hitung }}>\mathrm{T}_{\text {tabel, }}$ atau $9.2803<-1.9934$ dengan signifkansi 5\%, maka keputusannya yaitu hipotesis $\mathrm{H}_{\mathrm{a}}$ diterima dan hipotesis $\mathrm{H}_{0}$ ditolak, yang berarti secara parsial inflasi berpengaruh signifikan dan negatif terhadap pertumbuhan ekonomi di Indonesia.

\subsubsection{Uji F}

Uji F dilakukan untuk mengetahui seberapa besar pengaruh variabel jumlah uang beredar, suku bunga dan inflasi secara serentak (bersama-sama) terhadap variabel dependen yaitu pertumbuhan ekonomi di Indonesia dengan tingkat kepercayaan 95\% $(\alpha=5 \%)$. Pengujian hipotesis dengan uji $\mathrm{F}$ dilakukan dengan membandingkan $F_{\text {hitung dengan }}$ $\mathrm{F}_{\text {tabel. }}$.

Dari hasil pengujian di atas pada tabel 4.6 menunjukkan bahwa variabel jumlah uang beredar, suku bunga dan inflasi memiliki $F_{\text {hitung }}$ sebesar 63.46639 dengan nilai probabilitas statistiknya sebesar 0.000000 dan nilai $F_{\text {tabel }}$ dengan $(\mathrm{df})=\mathrm{n}-$ $\mathrm{k}=76-4=72$ dan $\mathrm{k}-1=4-1=3$ pada $\alpha=0,05$ diperoleh nilai sebesar 2,73. Dapat disimpulkan

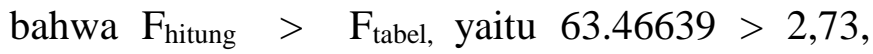


artinya secara serentak atau bersama- sama jumlah uang beredar, suku bunga dan inflasi berpengaruh positif dan signifikan terhadap pertumbuhan ekonomi di Indonesia.

\subsubsection{Koefisien Determinasi $\left(R^{2}\right)$}

Pengaruh dari jumlah uang beredar, suku bunga dan inflasi terhadap pertumbuhan ekonomi di Indonesia dilihat dari nilai $\mathrm{R}^{2}$. Dari hasil pengujian diperoleh nilai $\mathrm{R}^{2}$ sebesar 0,7142 yang berarti besarnya pengaruh dari variabel jumlah uang beredar, suku bunga, dan inflasi terhadap pertumbuhan ekonomi di Indonesia yaitu sebesar 0,7142 atau $71,42 \%$, sementara sisanya yaitu sebesar 28,58\% dipengaruhi oleh variabel lainnya yang tidak dimasukkan kedalam penelitian ini.

\subsubsection{Koefisien Korelasi ( $R$ )}

Maka hubungan antara jumlah uang beredar, suku bunga dan inflasi terhadap pertumbuhan ekonomi di Indonesia dilihat pada koefisien korelasi $(\mathrm{R})$ yaitu dengan cara mengakarkan nilai $\mathrm{R}^{2}$ yaitu: $\sqrt{ } 0,7142=0,8451$. Dari perolehan hasil tersebut, maka diketahui nilai koefisien korelasi adalah 0,8451 , artinya hubungan antara variabel jumlah uang beredar, suku bunga, inflasi dan pertumbuhan ekonomi tahun sebelumnya berhubungan sangat kuat secara positif terhadap pertumbuhan ekonomi, karena nilai korelasi sebesar 0.8451 mendekati posotif satu $(+1)$.

\subsection{Pembahasan}

\subsubsection{Pengaruh Jumlah Uang Beredar Terhadap Pertumbuhan Ekonomi}

Hasil penelitian menjelaskan variabel jumlah uang beredar memiliki pengaruh positif dan signifikan terhadap pertumbuhan ekonomi di Indonesia. Hasil ini sesuai dengan hipotesis yaitu jumlah uang beredar mempunyai pengaruh terhadap pertumbuhan ekonomi. Hasil ini memberikan bukti semakin meningkat jumlah uang beredar maka dapat meningkatkan pertumbuhan ekonomi, hal ini terkait karena dengan peningkatan jumlah uang beredar, maka masyarakat akan menempatkan sebagian dananya untuk konsumsi sehingga membuat produsen memproduksi barang lebih banyak kemudian permintaan akan faktor produksi meningkat. Hal ini akan berpengaruh pada pendapatan perkapita kemudian akan meningkatkan pertumbuhan ekonomi.

Hasil penelitian yang sama terjadi pada penelitian Tiwa \& Dkk (2016), dimana jumlah uang beredar mempunyai pengaruh terhadap pertumbuhan ekonomi. Hal ini terkait karena kenaikan jumlah uang beredar maka akan menyebabkan kenaikan investasi yang kemudian akan berdampak pada pertumbuhan ekonomi.

\subsubsection{Pengaruh Suku Bunga Terhadap Pertumbuhan Ekonomi}

Hasil penelitian menjelaskan variabel suku bunga berpengaruh positif terhadap pertumbuhan ekonomi di Indonesia. Hasil ini sesuai hipotesis dimana hipotesis menyatakan bahwa suku bunga berpengaruh terhadap pertumbuhan ekonomi. Hasil ini memberikan bukti tingkat suku bunga merupakan fungsi dari investasi. Tingkat suku bunga yang rendah dapat membuat investasi meningkat dan pada akhirnya akan berpengaruh pada pertumbuhan ekonomi yang akan meningkat. Hasil ini sesuai teori dimana teori menyatakan apabila suku bunga tinggi, maka jumlah investasi akan berkurang yang artinya pertumbuhan ekonomi akan turun, sebaliknya apabila suku bunga rendah maka akan mendorong banyak investasi yang sehingga dapat meningkatkan pertumbuhan ekonomi (Sukirno: 2010). Hal ini memberikan bukti bahwa suku bunga memiliki pengaruh terhadap pertumbuhan ekonomi baik itu secara positif maupun negatif.

\subsubsection{Pengaruh Inflasi Terhadap Pertumbuhan Ekonomi}

Hasil penelitian menjelaskan inflasi memiliki pengaruh negatif dan signifikan terhadap pertumbuhan ekonomi. Hal ini sesuai hipotesis bahwa inflasi mempunyai pengaruh terhadap pertumbuhan ekonomi di Indonesia. Hasil ini memberikan bukti bahwa semakin meningkat inflasi maka akan menurunkan laju pertumbuhan ekonomi, ini karena dengan peningkatan laju inflasi yang dapat menyebabkan kurangnya investasi di suatu negara, mendorong kenaikan 
suku bunga serta penanaman modal yang bersifat spekulatif, kegagalan pelaksanaan pembangunan, ketidakstabilan ekonomi, defisit neraca pembayaran, dan merosotnya tingkat kesejahteraan dan kehidupan masayrakat, yang pada akhirnya akan berimbas pada menurunnya pertumbuhan ekonomi.

Hasil penelitian yang sama terjadi pada penelitian Murialti dan Michel (2015), dimana inflasi memiliki pengaruh terhadap pertumbuhan ekonomi. Hal ini terkait karena kenaikan inflasi maka akan menyebabkan berkurangnya investasi dan penanaman modal asing yang kemudian akan berdampak pada pertumbuhan ekonomi.

\section{KESIMPULAN DAN SARAN}

\subsection{Kesimpulan}

Berdasarkan hasil penelitian dan pembahsan, maka dapat disimpulkan sebagai berikut:

1. Secara parsial jumlah uang beredar, dan inflasi berpengaruh secara positif dan signifikan terhadap pertumbuhan ekonomi di Indonesia, sedangkan suku bunga secara parsial tidak berpengaruh terhadap pertumbuhan ekonomi di Indonesia.

2. Secara serentak jumlah uang beredar, suku bunga dan inflasi berpengaruh positif dan signifikan terhadap pertumbuhan ekonomi di Indonesia.

3. jumlah uang beredar, suku bunga dan inflasi berpengaruh terhadap pertumbuhan ekonomi di Indonesia sebesar 0,7142 atau $71,42 \%$, sementara sisanya yaitu 0,2858 atau $28,58 \%$ dipengaruhi oleh variabel lainnya diluar model ini.

\subsection{Saran}

Berdasarkan hasil penelitian maka dapat diberikan saran-saran sebagai berikut:

1. Bank Indonesia diharapkan berhati-hati ketika mengeluarkan kebijakan dalam menaikkan tingkat suku bunga serta memperhatikan laju inflasi yang telah ditetapkan. Hal ini, guna memenuhi tujuan utama dari Bank Indonesia yakni memelihara nilai rupiah yang stabil untuk mendorong pertumbuhan ekonomi..
Bukan hanya untuk menarik investasi modal asing langsung ke Indonesia.

2. Untuk peneliti lain yang ingin meneliti tentang pertumbuhan ekonomi di Indonesia, ada baiknya menambahkan variabel lain untuk diteliti, karena ada cukup banyak variabel yang mempengaruhi pertumbuhan ekonomi di Indonesia.

\section{DAFTAR PUSTAKA}

Arsyad, L. (1997). Ekonomi Pembanguna. STIE YKPN: Yogyakarta.

Boediono. (1992). Teori Pertumbuhan Ekonomi. BPFE UGM: Yogyakarta.

Boediono. (1994). Ekonomi Moneter, Seri Sinopsis Pengantar Ilmu Ekonomi No 2. BPFE: Yogyakarta.

Boediono. (1998). Ekonomi Moneter, Seri Sinopsis Pengantar Ilmu Ekonomi. BPFE: Yogyakarta.

Dajan, A. (2000). Pengantar Metode Statistik. LP3ES: Jakarta.

Djojohadikusumo, S. (1993). Perkembangan Pemikiran Ekonomi: Dasar Teori Ekonomi Pertumbuhan dan Ekonomi Pembangunan. Edisi Pertama. Pustaka LP3ES: Jakarta.

Hubbard, \& Dkk. (2005). Effects Of The Real Exchange Rate On Output And Inflation: Evidence From Turkey. The Developing Economies. XL-4 December 2003: 401435.

Komariyah, \& Dkk. (2016). Manajemen Sumber Daya Manusia. Cetakan Ke-1. Alfabeta: Bandung.

Kunarjo. (2003). Perencanaan dan Pengendalian Program Pembangunan. UI-Press: Jakarta.

Murialti, N., \& Michel. (2015). Pengaruh Suku Bunga Dan Inflasi Terhadap Pertumbuhan Ekonomi Di Indonesia Tahun 1998-2013. Jurnal Akutansi \& Ekonomika: Universitas Muhammadiyah Riau, 5(2). 
Siburian, \& Dkk. (2013). Manajemen Pendidikan dan Komunikasi. Alfabeta: Bandung.

Sudarso. (1991). Pengantar Ekonomi Makro. PT Rineka Cipta: Jakarta.

Sugiyono. (2011). Metode Kuantitatif Kualitatif dan R \& D. Alfabeta: Bandung.

Tiwa, F. R., Rumate, V., \& Tenda, A. (2016). Pengaruh Investasi, Suku Bunga Sertifikat Bank Indonesia ( SBI ) Dan Jumlah Uang Beredar Terhadap Pertumbuhan Ekonomi Indonesia Tahun 2005-2014. Jurnal Berkala Ilmiah Efisiensi, 16(2).

Yodiatmaja, B. (2012). Hubungan Antara BI Rate dan Inflasi Periode Juli 2005 Desember 2011: Uji Kausalitas TodaYamamoto. Universitas Negeri Semarang: Indonesia. 